\title{
Gambaran Diri Pasien Amputasi Transtibial Akibat Kusta Setelah Menggunakan Transtibial Prosthesis dengan Kompenen ICRC
}

\author{
Nur Rachmat ${ }^{1}$, Faried Effendi Surono ${ }^{2}$ \\ Jurusan Ortotik Prostetik Poltekkes Kemenkes Surakarta \\ Email : $\underline{\text { dosenop@gmail.com }}$
}

\begin{abstract}
Abstrak
Latar belakang, Penilaian individu terhadap tubuh dan penampilannya disebut citra diri. Dalam tindakan amputasi karena kusta berkaitan erat dengan citra tubuh yang akhirnya mempengaruhi citra diri penampilan seseorang baik secara psikologis maupun psikologis. Klien amputasi transfoliatif melaporkan ketidaknyamanan sosial yang terkait dengan perubahan citra tubuh, penghargaan tubuh negatif, kurangnya dukungan sosial, dan meningkatnya depresi serta gangguan stres pascatrauma. Prostesis Transtibialis dengan komponen ICRC adalah intervensi instrumen berupa prostesis dengan dipasangkan di luar tubuh yang bertujuan mengembalikan bentuk ekstremitas bawah dan dapat menggantikan fungsi anatomis dan fungsional yang diharapkan juga mampu meningkatkan kepercayaan diri secara fisik dan psikis terhadap citra tubuh (bentuk tubuh) pasien dengan amputasi transtibialis. Metode: tipe kualitatif dengan metode penelitian yang digunakan yaitu wawancara dan observasi. Hasil: Bahwa peningkatan amputasi transtibial selfimage karena kusta setelah menggunakan prosthesis transtibial. Kesimpulan: Berdasarkan hasil pengamatan, wawancara dan analisis yang dilakukan pada penggunaan Prostesis Transtibial, pasien sekarang merasakan kemajuan dalam kegiatan mereka berkat menggunakan prosthesis terutama ketika aktivitas harus di depan umum
\end{abstract}

Kata kunci Gambaran Diri, kusta, ICRC, Transtibial Prosthesis

\section{Self Description of Patient Transtibial Amputation Due to Leprosy After Using Transtibial Prosthesis with Kompenen ICRC Abstract}

Background, Individual assessment of the body and its appearance is called theself image. In the act of amputation because leprosy is closely related to the body image that ultimately affects the self-image of a person's appearance both psychologically and psychologically. Transfoliative amputation clients report social discomfort associated with changes in body image, negative body esteem, lack of social support and increased depression and post-traumatic stress disorder. Transtibial Prosthesis with ICRC componen is an instrument intervention in the form of a prosthesis by being paired outside the body which aims to restore the lower limb shape and can replace the function anatomically and functionally is expected also able to increase the confidence physically and psychically to the body image (form body) of patients with transtibial amputation. Method: type is qualitative with research method that is used that is interview and observation. Result: That the increase of selfimage transtibial amputations because leprosy after using the transtibial prosthesis. Conclusion: Based on the results of observations, interviews and analysis carried out on the use of Transtibial Prosthesis, patients now feel progress in their activities thanks to using prosthesis especially when the activity must be in public

Keywords : Self Image;Leprosy;ICRC;Transtibial Prosthesis

\section{Pendahuluan}

Amputasi dapat diartikan sebagai tindakan memisahkan bagian tubuh sebagian atau seluruh bagian ekstremitas. Tindakan ini merupakan tindakan yang dilakukan dalam kondisi pilihan terakhir manakala masalah organ yang terjadi pada ekstremitas sudah tidak mungkin dapat diperbaiki dengan menggunakan teknik lain, atau manakala kondisi organ dapat membahayakan keselamatan tubuh klien secara utuh atau merusak organ tubuh yang lain seperti dapat menimbulkan komplikasi infeksi (healthy enthusiast). Menurut Qkey sekitar 75\% amputasi terjadi 
pada pria. Baik amputasi yang terjadi karena pekerjaan, penyakit dan penyebab lain, insidennya lebih tinggi pada pria. $85 \%$ amputasi terjadi pada ekstremitas bawah dan indikasi pada amputasi ada 3D yaitu: (1) Dead (dying), (2) Dangerous, (3) damn nulsance. Berdasarkan penelitian, pada saat ini amputasi pada alat gerak bawah mencapai $85-90 \%$ dari seluruh amputasi dan amputasi bawah lutut (transtibial amputation) merupakan jenis operasi amputasi yang paling sering dilakukan (Vitriana, 2002). Menurut Vitriana angka insidensi dan prevalensi amputasi yang pasti tidak diketahui, tetapi di Amerika Serikat saat ini terjadi 43.000 amputasi per tahun dari jumlah penduduk 280.562.489 jiwa.

Penyebab amputasi dan kondisi medis yang berhubungan dengannya sering menjadi pertimbangan yang penting untuk mengembangkan program manajemen pasien dengan amputasi. Penyebab amputasi sendiri secara umum dapat dibedakan menjadi : (1) efek lahir congenital $5 \%$ dengan mayoritas tampak pada usia dari lahir hingga 16 tahun, (2) penyakit oklusi arterial $60 \%$ yang sering dihubungkan dengan diabetes mellitus dengan insidensi pada usia sekitar 60-70 tahun $90 \%$ kasus melibatkan alat gerak bawah, (3) trauma, maupun (4) Penyebab amputasi salah satunya adalah penyakit kusta. Kusta atau leprae adalah penyakit yang disebabkan oleh bakteri Mycobacterium leprae. Penyakit ini menyerang berbagai tubuh termasuk saraf dan kulit menurut Pusat Data dan Informasi Kementrian Kesehatan. Menurut Dinas Kesehatan Jawa Timur per 11 Januari 2009 jumlah penderita penyakit kusta di Jawa Timur masih 2.610 orang. Penderita kusta di Jawa Timur paling banyak berada di Madura dengan rincian 381 orang di Sumenep, 232 orang di Sampang dan 207 orang di Bangkalan. Selain itu penderita kusta ada di Pasuruan (193 orang), Kabupaten Lumajang (171 orang), Probolinggo (125 orang), Tuban (92 orang) dan Pamekasan (65 orang).

Transtibial Prosthesis adalah suatu intervensi alat yang berupa alat gerak ganti (prosthesis) dengan cara dipasangkan diluar tubuh yang bertujuan untuk mengembalikan bentuk tungkai bawah dan dapat mengganti fungsi secara anatomis maupun fungsional yang diharapkan juga mampu menambah kepercayaan diri secara fisik maupun psikis terhadap citra tubuh (bentuk tubuh) pasien yang mengalami amputasi transtibial. Transtibial prosthesis memiliki berbagai macam desain yang setiap desainnya memiliki maksud dan tujuan sesuai kebutuhan pengguna. Desain yang ditentukan akan berpengaruh terhadap komponen dari transtibial prosthesis.

Sejak didirikan pada tahun 1979, Program Rehabilitasi Fisik ICRC telah mempromosikan penggunaan teknologi yang sesuai dengan konteks spesifik tempat organisasi beroperasi, yaitu, negara-negara yang terkena dampak perang dan negaranegara berpenghasilan rendah atau berkembang.Teknologi ini juga harus dirancang untuk memenuhi kebutuhan para penyandang cacat fisik di negara-negara yang bersangkutan.Oleh karena itu, teknologi yang diadopsi harus: (1) tahan lama, nyaman, mudah bagi pasien untuk digunakan dan dirawat, (2) mudah bagi teknisi untuk belajar, menggunakan dan memperbaiki, (3) terstandarisasi tetapi kompatibel dengan iklim di berbagai wilayah di dunia, (4) murah namun modern dan konsisten dengan standar yang diterima secara internasional.

Motivasi untuk studi kasus ini adalah ICRC lebih memilih untuk mengembangkan tekniknya sendiri daripada membeli komponen ortopedi siap pakai, yang umumnya terlalu mahal dan tidak sesuai dengan konteks di mana organisasi bekerja. Biaya bahan yang digunakan dalam perangkat prostetik dan ortotik ICRC lebih rendah daripada bahan yang digunakan 
dalam peralatan yang dirakit dari komponen siap pakai komersial. Menggunakan Polypropylene (PP) ke proyek ICRC pada tahun 1988 untuk pembuatan soket prostetik. Sendi polipropilen pertama diproduksi di Kamboja pada tahun 1991; komponen lain seperti berbagai sistem pelurusan pertama kali dikembangkan di Kolombia dan secara bertahap ditingkatkan

\section{Metode}

Subjek penelitian ini adalah satu pasien laki-laki penyandang amputasi transtibial karena kusta dengan kompenen ICRC yang berumur 52 tahun, pekerjaan sebagai buruh, hobi memancing, pada tahun dilakukan proses amputasi yang diakibatkan oleh kusta pada tungkai bawah sisi kiri (Gambar1). Sedangkan kelas ekonomi pasien pada golongan menengah kebawah.

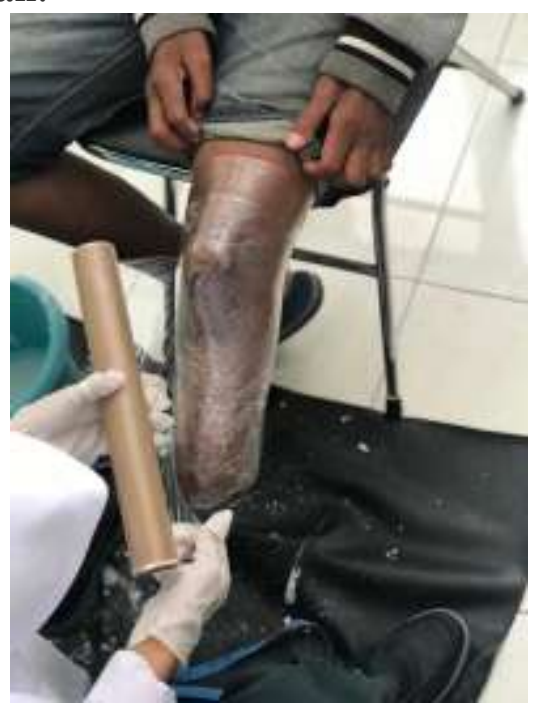

Gambar 1. Penampilan dari stump pasien dengan amputasi pala level transtibial.

Dengan penggunaan komponen ICRC (International Committee of the Red Cross) Pasien dengan golongan menengah kebawah sudah bisa menggukan komponen endoskeletal dan untuk memudakan pembuatan prosthesis itu sendiri.

Untuk semua alasan ini, ICRC lebih memilih untuk mengembangkan tekniknya sendiri daripada membeli komponen ortopedi siap pakai, yang umumnya terlalu mahal dan tidak sesuai dengan konteks di mana organisasi bekerja. Biaya bahan yang digunakan dalam perangkat prostetik dan ortotik ICRC lebih rendah daripada bahan yang digunakan dalam peralatan yang dirakit dari komponen siap pakai komersial.

Menggunakan Polyethylene (PE) ke proyek ICRC pada tahun 1988 untuk pembuatan soket prostetik. Sendi polipropilen pertama diproduksi di Kamboja pada tahun 1991; komponen lain seperti berbagai sistem pelurusan pertama kali dikembangkan di Kolombia dan secara bertahap ditingkatkan. Secara paralel, kaki yang tahan lama, awalnya terbuat dari polypropylene dan EthylVinylAcetate (EVA), dan sekarang dari polypropylene dan polyurethane, menggantikan kaki kayu / karet tradisional. Kompenen dari ICRC adalah sebagai berikut : (1) Convex ankle, (2) Two concave cylinders, (3) Convex disc, (4) Cylindrical TT cup, (5) Flat steel washer and countersunk head bolt, (6) Solid Ankle Cushion Heel (SACH) foot, (7) Hexagonal head bolt and lock washer.

Penelitian ini menggunakan penelitian kualitatif. Penelitian kualitatif menghasilkan dan mengolah data yang bersifat deskriptif. Dalam penelitian ini, penulis ingin memberikan deskripsi mengenai perubahan beberapa aspek pada pasien penyandang amputasi transtibial yang menggunakan transtibial prosthesis, dan tidak ada hipotesis yang diuji meskipun menggunakan teori yang ada.

Metode penelitian yang digunakan dalam penelitian ini adalah penelitian ini dilakukan dengan studi kasus yang bersifat intrinsik, yaitu kasus yang diambil merupakan kasus yang menarik untuk diteliti. Menurut Moleong (1998) studi kasus merupakan metode untuk menghimpun dan menganalisis data berkenaan dengan studi kasus. Sesuatu dijadikan studi kasus biasanya karena ada masalah, kesulitan, hambatan, penyimpangan, tetapi bisa juga sesuatu dijadikan kasus meskipun tidak ada 
masalah, melainkan karena keunggulan atau keberhasilannya.

\begin{tabular}{|c|c|c|}
\hline $\begin{array}{l}\text { Pertanyaan } \\
\text { Penggunaan } \\
\text { Prosthesis }\end{array}$ & Sebelum & Sesudah \\
\hline $\begin{array}{l}1 . \quad \text { Bagaimana } \\
\text { kenyaman prosthesis } \\
\text { pada saat berdiri? }(-0) \\
(+10)\end{array}$ & 5 & 10 \\
\hline $\begin{array}{l}2 . \quad \text { Bagaimana } \\
\text { kenyaman prosthesis } \\
\text { pada saat berjalan? (- } \\
0)(+10)\end{array}$ & 5 & 9 \\
\hline $\begin{array}{l}3 . \quad \text { Bagaimana } \\
\text { kenyaman prosthesis } \\
\text { pada saat duduk? }(-0) \\
(+10)\end{array}$ & 5 & 9 \\
\hline $\begin{array}{l}\text { 4. Bagaimana rasa } \\
\text { keamanan } \\
\text { prosthesis? }(-0)(+10)\end{array}$ & 8 & 10 \\
\hline $\begin{array}{l}\text { 6. Apakah anda } \\
\text { senang dengan } \\
\text { pemakaian } \\
\text { prosthesis? }(-0)(+10)\end{array}$ & 8 & 10 \\
\hline $\begin{array}{l}\text { 7. Seberapa fit } \\
\text { prosthesis yang anda } \\
\text { gunakan? }(-0)(+10)\end{array}$ & 8 & 9 \\
\hline $\begin{array}{l}\text { 8. Seberapa berat } \\
\text { prosthesis yang anda } \\
\text { gunakan? }(-0)(+10)\end{array}$ & 4 & 2 \\
\hline $\begin{array}{l}\text { 9. Seberapa stabil } \\
\text { prosthesis yang anda } \\
\text { gunakan? }(-0)(+10)\end{array}$ & 8 & 10 \\
\hline $\begin{array}{l}\text { 10. Seberapa jauh } \\
\text { anda dapat berjalan? } \\
(-0)(+10)\end{array}$ & 3 & 4 \\
\hline $\begin{array}{l}\text { 11. Bagaimana rasa } \\
\text { sakit setelah } \\
\text { menggunakan alat? (- } \\
\text { 0) }(+10)\end{array}$ & 3 & 3 \\
\hline $\begin{array}{l}\text { 12. Bagaimana tingkat } \\
\text { kelelahan? }(-0)(+10)\end{array}$ & 4 & 4 \\
\hline
\end{tabular}

Tabel 1. Hasil Dari Kesimpulan Wawancara Subjek Pada Saat Menggunakan Prosthesis Dengan Komponen ICRC

Tujuan dari studi kasus adalah untuk memberikan gambaran secara mendetail tentang latar belakang, sifat- sifat serta karakter yang khas dari kasus, ataupun status dari individu, yang kemudian dari sifat-sifat khas tersebut akan dijadikan suatu hal yang bersifat umum. Sedangkan menurut Moleong (2000) pendekatan kualitatif adalah pendekatan yang bermaksud untuk memahami fenomena tentang apa yang dialami oleh subjek penelitian misalnya perilaku persepsi, motivasi, tindakan dan lain- lain. Secara holistik, dan dengan cara deskripsi dalam bentuk kata-kata dan bahasa, pada suatu konteks khusus yang alamiah dan dengan memanfaatkan berbagai metode alamiah.

Pendekatan penelitian adalah murni kualitatif dengan menggunakan metodemetode kontak langsung, yakni wawancara. Peneliti akan melakukan penelitian kualitatif dengan metode pengumpulan data secara wawancara terfokus (Poerwandari. 2001). Efektivitas penggunaan transtibial prosthesis terhadap body image pasien amputasi transtibial ini akan diteliti dari data konkrit. Dimana subjek penelitian ini pasien amputasi transtibial dengan cara wawancara terfokus langsung pada pasien yang bersangkutan.

\section{Hasil Penelitian}

Analisis Alat Hasil Observasi dari penggunaan Transtibial Prosthesis menggunakan komponen ICRC. Dari hasil observasi penggunaan transtibial prosthesis dengan kompenen ICRC dapat dilihat bahwasannya pasien merasa mempunyai citra yang lebih baik karena memiliki kembali tungkainya yang hilang. Sebelum memakai alat, terkadang pasien menyadari hal-hal negatif tentang dirinya yang dibandingkan dengan orang lain dan juga merasa aneh saat melihat dirinya sendiri.

Meskipun di keseharianya pasien tidak pernah merasa rendah diri dan mendapat dukungan dari banyak orang namun sesekali itu yang dirasakan oleh pasien. Kemudian setelah menggunakan dan belajar bagaimana pemakaian prosthesis pasien mulai menyadari dia lebih optimis ketika berada di luar ataupun saat 
bepergian jauh. Berdasarkan keterangan dari teman pasien yakni Tn. DG, selama ini Tn. DG mengenal Tn. GS adalah opis yang menangani kasus Tn. DG adalah sosok pribadi yang ramah, enjoy dan mudah bergaul. Kondisinya yang sekarang benar - benar tidak mempengaruhinya dalam pergaulan secara umum dan menurutnya Tn. GS merasa biasa saja dan menerima citra tubuhnya dengan baik apalagi ketika melihat Tn. GS yang memakai kaki tiruan (prosthesis) dia merasa bahwa Tn. HS semakin optimis saat melakukan aktivitasnya yang kebanyakan berada diluar ruangan.

Ketika pasien melakukan proses latihan menggunakan prosthesis yang kedua tidak banyak penyimpangan pola jalan yang diperoleh pasien. Pola jalannya cukup baik dan yang terpenting pasien merasa nyaman saat melangkahkan kakinya walaupun itu baru kali pertama bagi pasien dengan kondisi teramputasi. Waktu yang dibutuhkan pasien untuk melakukan pelatihan pemakaian prosthesis juga relatif singkat yakni sekitar beberapa minggu. Disamping melakukan pelatihan pasien juga memperbaiki pola jalannya agar terlihat seperti orang normal yang ketika berjalan seperti tidak menggunakan prosthesis. Sampai sekarang pasien sudah mengganti prosthesisnya sebanyak 1 kali. Selain itu pasien juga rutin merawat stumpnya apabila tejadi lecet akibat pemakaian prosthesis yang terus menerus dan untuk menjaga kebersihan stumpnya.

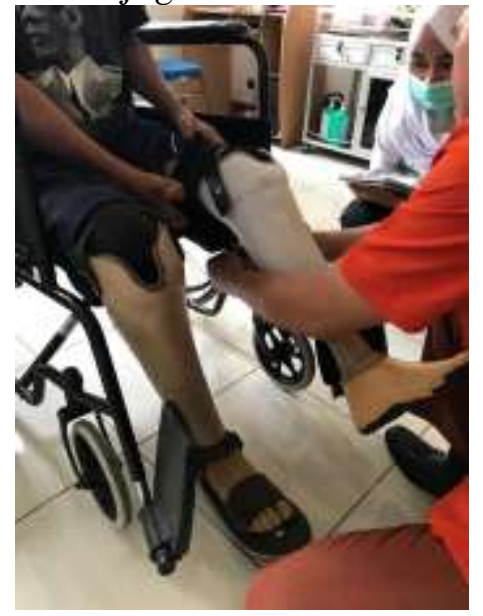

Gambar 3. (A) Pemakaian Prosthesis

\section{Pembahasan}

Dalam analisa ini terdapat gambaran umum subjek, hasil observasi pemakaian transtibial prosthesis dengan komponen ICRC dan hasil wawancara dengan keluarga subjek tentang kondisi pasien sebelum dan sesudah menggunakan transtibial prothesis.

Gambaran umum dari subjek Tn. DG berumur 55 tahun, tempat tinggal di lingkungan pondok sosial Surabaya. Penyebab amputasi pasien yakni dikarenakan kusta pada tahun 2009 dengan tidak adanya keluarga lain yang pernah mengalami kusta yang awalnya pasien merasakan adanya panu didaerah muka lalu diobati dengan obat antibiotik panu tetapi panu tidak kunjung sembuh selama dua bulan, setelah bulan keempat bercak putih yang di duga oleh pasien adalah panu mulai muncul di daerah perut, kemudian setelah tidak mendapatkan penangan medis muncul bintik-ntik kemerahan yang mulai tersebar pada kulit dan pasien mulai merasakan demam dari derajat yang panas sampai dengan menggigil, pasien mulai memeriksakan diri ke puskemas dan mendapati di diagnosa terkena ciri-ciri kusta, setelah ditangani oleh pihak puskemas pasien sudah mulai mengalami sendi pada jari-jari mulai kaku, mudah cape, jika terjadi luka tidak sumbuh pada bagian kaki dan pasien mulai sering merakan mati rasa pada baian tungkai bawah sampai kaki dikarenakan pada bagian kaki terkena luka yang tidak dapat sembuh dan hanya diperban lalu disarankan ditangani oleh RS Sumber Glagah pasien ditangani selama masa karantina 6 bulan untuk proses penyembuhan dari kusta, pasien dinyatakan sembuh dari kusta setelah 1 tahun lamanya setelah dirawat dan meminum obat secara rutin dan dilakukan proses amputasi pada kaki kiri pada bagian bawah lutut atau transtibial tahun 2012 dikarenan bentuk dari kaki pasien mengganggu aktivitas mandiri dan 
mencegah untuk terjadinya deformitas lainnya. Pasien merasakan depresi dikarenakan ada bagian tubuh yang diamputasi tetapi karena banyaknya dukungan yang positif dari pihak teman yang juga terkana kusta, didukung oleh pihak dokter dan rehab medis bahwa ada solusi untuk membatu mobilitas pasien kembali yaitu dengan proses pembuatan kaki palsu dan pada tahun 2016 pasien mulai di proses untuk pembuatan kaki palsu dan pasien juga terapi latihan jalan.

Penelitian ini sejalan dengan penelitian yang dilakukan oleh Nur Rachmat pada tahun 2016 dengan judul perbedaan pengaruh penggunaan prostesis transtibal terhadap kepercayaan diri pada pasien post amputasi trasntibial bahwa penggunaan prosthesis sangat berpengaruh pada kepercayaan diri pasien post amputasi Transtibial. Hal ini terlihat pada hasil pengukuran kepercayaan diri pasien antara sebelum dan sesudah menggunakan prosthesis dimana kepercayaan diri pasien sebelum menggunakan prosthesis lebih banyak yang mempunyai kepercayaan diri yang rendah yaitu sebanyak $15(48,4 \%)$ dari 31 pasien. Sedangkan setelah pasien menggunakan prosthesis dan mendapatkan pelatihan penggunaannya lalu diukur kepercayaan dirinya ternyata lebih banyak yang mempunyai kepercayaan diri yang tinggi yaitu sebanyak13 (41,9\%). Timbulnya kepercayaan diri bisa disebabkan oleh karena pasien mempunyai keinginan dan tekat yang kuat agar dapat beraktifitas lagi seperti semula walaupun dengan menggunakan kaki palsu. Selain itu kemampuan pasien dalam menggunakan kaki palsu setelah dilatih dan keberhasilannya dalam melakukan aktifitas merupakan faktor yang sangat berpengaruh juga terhadap peningkatan rasa percaya diri pasien. Hal ini sesuai dengan penelitian yang pernah dilakukan oleh Lobes Herdiman dkk, (2010) dengan judul "Kajian biomekanika untuk jalan cepat terhadap penggunaan prosthesis di Lab perencanaan dan perancangan produk Surakarta. Hasil penelitian menunjukkan bahwa penggunaan prosthesis tidak mempengaruhi keseimbangan pola jalan, dimana kaki yang menggunakan prosthesis mampu mengayunkan langkah kaki dengan tidak memerlukan energi yang besar. Dengan demikian pasien yang menggunakan kaki palsu akan dapat bergerak atau beraktifitas tanpa adanya gangguan dan tetap terjaga keseimbangan pola jalannya.

Penelitian yang dilakukan juga oleh Maretania Devi pada tahun 2018 dengan judul body image pasca amputasi transtial setelah menggunakan transtibial prosthesis bahwa Dari hasil observasi penggunaan transtibial prosthesis dapat dilihat bahwasannya pasien merasa mempunyai citra yang lebih baik karena memiliki kembali tungkainya yang hilang. Sebelum memakai alat, terkadang pasien menyadari hal-hal negatif tentang dirinya yang dibandingkan dengan orang lain dan juga merasa aneh saat melihat dirinya sendiri. Meskipun di keseharianya pasien tidak pernah merasa rendah diri dan mendapat dukungan dari banyak orang namun sesekali itu yang dirasakan oleh pasien. Kemudian setelah menggunakan dan belajar bagaimana pemakaian prosthesis pasien mulai menyadari dia lebih optimis ketika berada di luar ataupun saat bepergian jauh, dengan subjek Tn.HS berumur 23 tahun, pada saat masih di bangku Sekolah Menengah Atas (SMA) mengalami trauma karena kecelakaan lintas yang mengakibatkan cedera hebat pada tungkai sebelah kanan.

Analisis alat hasil observasi dari penggunaan Transtibial Prosthesis menggunakan komponen ICRC. Dari hasil observasi penggunaan transtibial prosthesis dengan kompenen ICRC dapat dilihat bahwasannya pasien merasa mempunyai citra yang lebih baik karena memiliki kembali tungkainya yang hilang. Sebelum memakai alat, terkadang pasien menyadari hal-hal negatif tentang dirinya yang 
dibandingkan dengan orang lain dan juga merasa aneh saat melihat dirinya sendiri. Meskipun di keseharianya pasien tidak pernah merasa rendah diri dan mendapat dukungan dari banyak orang namun sesekali itu yang dirasakan oleh pasien. Kemudian setelah menggunakan dan belajar bagaimana pemakaian prosthesis pasien mulai menyadari dia lebih optimis ketika berada di luar ataupun saat bepergian jauh. Berdasarkan keterangan dari teman pasien yakni Tn. DG, selama ini Tn. DG mengenal Tn. GS adalah opis yang menangani kasus Tn. DG adalah sosok pribadi yang ramah, enjoy dan mudah bergaul. Kondisinya yang sekarang benarbenar tidak mempengaruhinya dalam pergaulan secara umum dan menurutnya Tn. GS merasa biasa saja dan menerima citra tubuhnya dengan baik apalagi ketika melihat Tn. GS yang memakai kaki tiruan (prosthesis) dia merasa bahwa Tn. DP semakin optimis saat melakukan aktivitasnya yang kebanyakan berada diluar ruangan.

Setelah tahun 2019 pasien mengganti kaki palsunya dikarenanan yang lama sudah banyak bagian rusak dan pada socket agak kebesaran dilakukan proses pembuatan kaki palsu di RS Sumber Glagah yang menggunakan komponen ICRC. Sekarang juga nyaman menggunakan prosthesis dalam seluruh aktivitasnya bekerja sebagai buruh dan hobinya yaitu memancing. Tipe prosthesis yang digunakan yakni transtibial prosthesis endoskeletal ICRC dengan socket jenis PTB with cuff suspension dan kaki jenis Sach Foot.

\section{Simpulan}

Berdasarkan hasil observasi, wawancara dan analisa yang dilakukan terhadap penggunaan Transtibial Prosthesis, kini pasien merasakan kemajuan dalam beraktivitas berkat menggunakan prosthesis terlebih saat aktivitas itu harus berada di muka umum. Dalam proses pembuatan alatnya dan pelatihan berjalan, pada pasien tidak ditemui pola jalan yang terlalu bermasalah, demikian menurut pasien berdasarkan yang disampaikan oleh ortotis prostetisnya. Maka dapat disimpulkan, bahwa penggunaan Transtibial Prosthesis dapat membantu menambah citra tubuh dengan cara menggantikan tungkai pasien yang hilang akibat amputasi.

Adapun saran yang dapat diberikan oleh peneliti yakni sebaiknya pasien yang mengalami operasi amputasi membuatkan alat gerak ganti untuk mengembalikan bagian yang telah hilang. Karena selain untuk menambah citra tubuh menjadi lebih baik, pembuatan prosthesis juga membantu secara anatomis dan dalam aktivitas fungsional.. Berdasarkan kesimpulan tersebut, beberapa saran dapat disampaikan, diantaranya: 1) Pengguna Alat menggunanan komponen ICRC dapat mengakomodasi dana pasien dengan ekonomi menengah kebawah dan juga mendapatkan prosteshis yang berkualitas; 2) perlu dilakukan penelitian sejenis dengan jumlah subjek yang lebih banyak dan dengan penggunaan transtibial prosthesis dengan komponen ICRC.

\section{Daftar Pustaka}

Cartwright, C.A, \& Cartwright, P,G, "Developing Observation Skills2nd ed, USA: Mc Graw- Hill, 1984.

Cash, T. F. (1994). Body Image Attitudes : Evaluation, Investment, \& Affect Perceptual and Motor Skills. Journal of Psychology, 78,1168-1170.

Handicap International. (2006). Guideline for Prosthesis Management. Handicap International, Paris.

Honigman, David j. Castle. (2007). Living With Your Looks. Victoria: University of Western Australia Press.

Moleong, J.L. (1998) Metodologi penelitian kualitatif. Bandung: PT. Remaja Rosdakarya.

Moleong, J.L. (2000) Metodologi penelitian kualitatif (Edisi Revisi). Bandung: PT. Remaja Rosdakarya.

Naimah, T. (2008). Pengaruh Komparasi Sosial pada Public Figure di Media Massa terhadap Body Image Remaja Di Kecamatan Patikraja, Kabupaten Banyumas. Jurnal Psikologi Penelitian Humaniora, 9, (2).

Patton, Q.M. (2002) Qualitative research and evaluation metode. 3nd ed. California: Sage 
Publication, Inc. Permenkes

RI.

(2013). Pengertian Ortotik Prostetik : 22.

Poerwandari, K. (2001) Pendekatan

Kualitatif Untuk Penelitian

Perilaku Manusia .Jakarta:

Lembaga PengembanganSarana

Pengukuran \& Pendidikan Psikologi

(LPSP 3) Universitas Indonesia.

Qkey. (2007). Free Medical Amputasi. Diakses tanggal 21/5/2019, dari http/www.freemedical.blogspot.com

Rahmat N. (2016) Perbedaan Pengaruh Penggunaan Prostesis Transtial Terhadap Kepercayaan Diri. Poltekkes Kemenkes Surakarta.

Santi M, Rahmat N. (2018) Gambaran Body Image Pasien Pasca Amputasi Transtibial Setelah Menggunakan Transtibial Prosthesis. Poltekkes Surakarta.

Tika Larasati. (2012). Jurnal Kualitas Hidup Pada Wanita Yang Sudah Memasuki Masa Menopause. Fakultas Psikologi Universitas Gunadarma, Depok.

Vitriana. (2002). Rehabilitasi Pasien Amputasi Bawah Lutut Dengan Menggunakan Immediate Post Operative Prosthetic. Penelitian Bagian Ilmu Kedokteran Fisik dan Rehabilitasi. FK-UNPAD, Bandung, hal 1-3.

Yin, R. (1994) Case study research design \& method. London: Sage Publication 